УДК 634.13+631.521:631.559

UDC 634.13+631.521:631.559

DOI 10.30679/2219-5335-2021-6-72-124-144

DOI 10.30679/2219-5335-2021-6-72-124-144

СРАВНИТЕЛЬНАЯ ОЦЕНКА ФИЗИОЛОГИЧЕСКИХ ПОКАЗАТЕЛЕЙ И АНАТОМО-МОРФОЛОГИЧЕСКИХ ОСОБЕННОСТЕЙ ЛИСТЬЕВ

РОДА PYRUS L. ДЛЯ ВЫЯВЛЕНИЯ

ИСТОЧНИКОВ АДАПТИВНОСТИ К ВОЗДЕЙСТВИЮ СТРЕССФАКТОРОВ ЛЕТНЕГО ПЕРИОДА В СЕЛЕКЦИИ*

\title{
COMPARATIVE ASSESSMENT OF PHISIOLOGICAL PARAMETERS AND ANATOMICAL AND MORPHOLOGICAL FEATURES OF LEAVES OF THE GENUS PYRUS L. TO IDENTIFY SOURCES OF ADAPTIVITY TO THE IMPACT OF SUMMER STRESS FACTORS IN BREEDING*
}

Киселева Наталья Станиславовна

Kiseleva Natalya Stanislavovna канд. биол. наук старший научный сотрудник лаборатории селекции e-mail: nskiselyeva_05@mail.ru

Федеральное государственное бюджетное учреждение науки «Федеральный исследовательский центр «Субтропический научный иентр Российской академии наук», Сочи, Россия

В условиях зоны влажных субтропиков России в течение 2002-2020 гг. проведена оценка степени засухоустойчивости сортов и гибридов груши по анатомо-морфологическим и физиологическим параметрам для изучения их адаптационных механизмов. Объекты исследования различные генотипы рода Pyrus $L$. (сорта: Бере Жиффар, Вега, Вильямс, Красный Вильямс, Черноморская Янтарная, Южанка, Нектарная, Славянка, Вербена, Лучистая, Бере Боск, Рассвет, гибрид 8520, Кильчу). Для оценки адаптационной устойчивости изучаемых сортов груши к стресс-факторам летнего периода (высоких температур и низкой

Cand. Biol. Sci.

Senior Research Associate

of Breeding Laboratory

e-mail: nskiselyeva_05@mail.ru

Federal State Budgetary

Institution of Science,

Federal Research Center

«Subtropical Scientific Center

of the Russian Academy of Sciences»,

Sochi, Russia

In condition of humid subtropical zone of Russia during 2002-2020, the degree of drought resistance of pear varieties and hybrids was assessed by anatomical, morphological and physiological parameters to study their adaptation mechanisms. Research's objects - different genotypes of genus Pyrus L. (varieties:

Bere Zhiffar, Vega, Williams, Red Williams, Chernomorskaya Yantarnaya, Yuzhanka, Nektarnaya, Slavyanka, Verbena, Luchistaya, Bere Bosk, Rassvet, hybrid 8520, Kilchu). A set of physiological, anatomical and morphological indicators was used to assess the adaptability of the studied pear varieties to stress factor

\footnotetext{
* Публикация подготовлена в рамках реализации ГЗ ФИЦ СНЦ РАН № 0492-2021-0009 (селекция)

* The publication was prepared in the framework of the implementation of the state assignment of FRC SSC of RAS № 0492-2021-0009 (breeding)
} 
влагообеспеченности) использовали комплекс физиологических

и анатомо-морфологических показателей.

Установлено, что изменение

физиологических процессов влияет

на анатомо-морфологическое строение

листа. Дана оценка засухоустойчивости

изучаемых сортов и гибридов по характеру

изменения параметров водного режима.

Определено, что водоудерживающая

способность листовой пластинки у всех

генотипов имеет высокую обратную

зависимость $(\mathrm{r}=-0,77)$ от числа устьиц

на нижнем эпидермисе листа.

По количественному соотношению

хлорофиллов a и b выделены сорта

Бере Жиффар, Бере Боск и Черноморская

янтарная, подтверждающие устойчивость

пигментной системы к водному дефициту

в наиболее засушливый период.

Отмечена непрерывная модификация

фотосинтетической функции листьев,

связанная с продуктивностью

и жизнеспособностью. Установлено,

что влияние стрессовых погодных условий

приводит к появлению у генотипа

таких ксероморфных признаков,

как усиленное развитие слоя палисадной

паренхимы и уменьшение количества устьиц

на единицу поверхности. Сорта Красный

Вильямс, Черноморская янтарная, Вега

и Рассвет выделены по комплексу

вышеперечисленных признаков как наиболее адаптивные к абиотическим стресс-факторам летнего периода влажных субтропиков.

Выявленные адаптивные особенности этих сортов позволят использовать их в селекции в качестве источников устойчивости к засухе.

Ключевые слова: ВИД, СОРТ, ГРУША, АДАПТАЦИЯ, ЗАСУХОУСТОЙЧИВОСТЬ, КСЕРОМОРФНЫЕ ПРИЗНАКИ ЛИСТА, ФИЗИОЛОГИЧЕСКИЕ ПАРАМЕТРЫ of the summer period (high temperature and low water-holding). It is established that change in the physiological processes affect the anatomical and morphological structure of the leaf. The assessment of drought resistance of the studied varieties and hybrids by the nature of changes in the parameters of the water regime is given. It was determined that water-holding capacity of the leaf blade in all genotypes has a high inverse dependence $(r=-0,77)$ on the number of stomates on lower epidermis of the leaf. According to quantitative ratio of chlorophylls a and $b$, the varieties Bere Zhiffar, Bere Bosk and Chernomorskaya Yantarnaya were identified, confirming stability of the pigment system to water deficit at the most arid period. Continuous modification of the photosynthetic function of leaves associated with productivity and viability was noted. It was found that the influence of stressful weather conditions leads to the appearance of such xeromorphic traits in the genotype as increased development of the palisade parenchyma layer and a decrease in the number of stomates per unit surface. Varieties Red Williams, Chernomorskaya Yantarnaya, Vega and Rassvet are identified by the complex of the above characteristics as the most adaptive to the abiotic stress factors of the summer period of humid subtropics. Revealed adaptive features of these varieties allow to use them in breeding as sources of resistance to drought.

Key words: TYPE, VARIETY, PEAR, ADAPTATION, DROUGHT TOLERANCE, XEROMORPHIC LEAF SIGNS, PHYSIOLOGICAL PARAMETERS

Введение. Груша - одна из наиболее распространенных плодовых культур, нуждающаяся в детальном изучении для отбора сортов, наиболее пригодных к почвенно-климатическим условиям влажных субтропиков 
России. Стрессовые факторы летнего периода - засуха и высокие температуры, негативно влияют на развитие деревьев и закладку генеративных органов, вызывая при этом опадение листьев и плодов. Подобные сезонные температурные воздействия приводят к снижению урожайности на 15-30 \%, вызывая изменения в метаболизме растений, фотосинтезе, водном обмене, что отражается на физиолого-биохимических и анатомоморфологических показателях [1-4]. Так как сорта должны быть не только высокопродуктивны, но и способны к быстрой и эффективной регуляции защитных механизмов при высокотемпературном стрессе, необходим отбор сортов, устойчивых к засухе и негативному воздействию высоких температур [6-8]. Изучение изменений толщины листа, соотношения тканей мезофилла, а также размеров клеток столбчатой и губчатой паренхимы на протяжении вегетации дает возможность сопоставить по этим показателям сорта, отличающиеся различной степенью устойчивости к засухе $[9,10]$. Таким образом, в определении степени засухоустойчивости, помимо физиологических особенностей, необходимо изучение анатомоморфологических особенностей строения листа.

Лист - пластичный вегетативный орган, реагирующий на изменение природных факторов $[11,12]$. Особенности водного режима, ксероморфная структуры листа служат надежными критериями засухоустойчивости растений [13-16]. Вследствие неблагоприятных почвенно-климатических условий у растений быстрее прекращается процесс нарастания площади листа. Кроме того, в период водного стресса происходит снижение толщины листовой пластинки, в то время как в оптимальных условиях выращивания ростовые процессы более продолжительны. Размер листовой пластинки и, следовательно, ассимиляционная поверхность в целом, в значительной степени определяет активность фотосинтеза через увеличение продуцируемости количества ассимилянтов, необходимых для жизнедея- 
тельности и развития плодов (помимо этого, размер листа часто является сортовой особенностью). Чем больше листовая поверхность, тем значительнее испарение воды и ниже устойчивость растений к дефициту воды, тем сильнее растение подвержено засухе.

В представленной работе впервые использован комплекс физиологических и анатомических показателей листовой пластинки для диагностики устойчивости сортов и гибридов груши разных сроков созревания к стрессфакторам летнего периода в условиях влажных субтропиков России. Выявлены особенности изучаемых генотипов в отношении перенесения высоких температур и засухи. Цель настоящей работы - по физиологическим и анатомо-морфологическим параметрам листа изучить особенности водного режима, фотосинтетической деятельности груши в условиях летнего периода, а также выделить наиболее засухоустойчивые сорта для возделывания в условиях влажных субтропиков России. В связи с этим в задачу наших исследований входило проведение сравнительной оценки сортов и гибридов груши разных сроков созревания по основным параметрам водного режима, фотосинтеза и анатомо-морфологических особенностей для изучения адаптационных механизмов приспособления к изменяющимся условиям среды.

Объекты и методы исследований. Исследования проведены в течение 2002-2020 гг. на базе коллекционных насаждений ФИЦ СНЦ РАН. Объектами исследования служили сорта и гибриды груши (Pyrus L.) разного срока созревания: раннелетние - Бере Жиффар (к), Вега; летние - Вильямс (к), Красный Вильямс, Черноморская янтарная, Южанка, Нектарная; осенне-зимние - Бере Боск (к), Славянка, Вербена, Лучистая, Рассвет, гибрид № 8520, Кильчу (Pyrus pyrifolia). Отбор полностью сформированных листьев проводился ежемесячно (июнь-сентябрь) с трех деревьев (со средней части однолетних приростов) каждого генотипа в 3-кратной биологи- 
ческой повторности, состоявшей из 10 листьев. Для оценки адаптационной устойчивости изучаемых сортов груши к стресс-факторам летнего периода использовали комплекс физиологических и анатомо-морфологических показателей. Исследования и отбор проводили по «Программе и методике сортоизучения плодовых, ягодных и орехоплодных культур», Орел, 1999 [7] и «Программе Северо-Кавказского центра по селекции плодовых, ягодных, цветочно-декоративных культур и винограда на период до 2030 года», Краснодар, 2013 [8]. Данные погодных условий взяты из отчетов Сочинской агроклиматической станции и pogodaiklimat.ru (Weather, 2019) [17]. Анатомо-морфологические и физиологические исследования проводили на лабораторной базе ФИЦ СНЦ РАН в соответствии с общепринятыми методиками $[5,7,8,14]$ : водный режим листьев - по описанным методикам $[7,8]$, содержание хлорофилла а и $\mathrm{b}$, а также каротиноидов - методом А.А. Шлыка $[13,14]$. Анатомические признаки листа оценивали по Н.С. Воронину [9] с использованием микроскопа «Биолам И», («ЛОМО», Россия), биометрические параметры листовой пластинки измеряли окуляр-микрометром (в мкм), промеры клеток и тканей велись при увеличении 10 х 40. Изучение функционального состояния растений по параметрам медленной индукции флуоресценции хлорофилла выполняли на портативном хлорофилл-флуориметре LPT-3C (Россия, ВСТИСП) в соответствии с методикой разработчиков [18, 19]. Анализ проводили в 7 повторностях (листовые пластинки) и в 5-ти точках промеров у плодов. Измерения осуществляли в период вегетации: в начале I декады июня; в условиях максимально повышенных температур и активного созревания плодов I-II декады июля-августа; затем в начале подготовки перехода растений к зимнему покою - II декаде сентября. С помощью компьютеризованной модели прибора в автоматическом режиме учитывались такие основные показатели как Fm/F_T (уровень жизнеспособности) и Kf_T (фото- 
Плодоводство и виноградарство Юга России № 72(6), 2021 г.

синтетическая активность по алгоритму экстраполяции), коэффициент безразмерен [18]. Статистический анализ экспериментально полученных данных осуществлен в программах STATISTICA 10 и пакете анализа данных MS Excel [20]. Существенность разницы между показателями $\left(\mathrm{HCP}_{05}\right)$ определяли с достоверной вероятностью $95 \%$.

Обсужнение результатов. В условиях влажных субтропиков юга России летняя засуха - один из основных стрессоров абиотического характера. Метеорологические условия периода вегетации в зоне проведения исследований существенно различается по годам, поэтому исходный селекционный материал, как и гибридный, на первых этапах отбора нуждается в оценке их устойчивости к отмеченному фактору.

Так, 2003 год был засушливым (осадки от 31-39 мм в мае-июне, 84,4 мм в апреле) при температуре от $17,3{ }^{\circ} \mathrm{C}$ (в мае) до $30,0{ }^{\circ} \mathrm{C}$ и выше (в июле-августе) с небольшим снижением относительной влажности воздуха (до 75 \%); в 2006 году отмечали высокую влагообеспеченность (количество осадков в мае-июне в среднем от 45 до 128 мм, в апреле - 156 мм). Жаркий и засушливый период июля-августа характеризовался высокой (до $36,0{ }^{\circ} \mathrm{C}$ в августе) температурой воздуха. Среднесуточная температура и количество осадков 2011-2020 гг. в целом были сопоставимы со средними многолетними данными зоны. Исходя из анализа полученной урожайности изученные годы по метеоусловиям можно разделить на относительно благоприятные (2011, 2013, 2014, 2018 и 2019 гг.) и неблагоприятные (2012, 2015, 2017 и 2020 гг.) для культуры. Так, в 2012 году зимние холода растянулись со 2-ой декады января и до марта. В 2017 году наблюдалась холодная весна, выраженная в возвращении низких температур в третьих декадах марта и апреля $\left(2,2-3,8{ }^{\circ} \mathrm{C}\right)$. Подобные погодные условия проявились угнетением ростовых процессов у груши, в частности цветения, и более поздним началом активной вегетации. Летние периоды 2012 и 2017 годов 
Плодоводство и виноградарство Юга России № 72(6), 2021 г.

отмечены неравномерностью выпадения осадков в течение вегетационного периода, частыми ливнями или отсутствием осадков в течение длительного периода. В июле-августе этих годов выпадение осадков составило 117 и 100 мл, что в августе 2017 года привело к замедлению роста побегов и листьев, развития и созревания плодов, и постепенном их восстановлении в течение всего летнего периода 2012 года. Показатели зимнего периода 2019-2020 годов характеризовались низкой среднесуточной температурой воздуха с абсолютным минимумом в феврале, когда минимальная температура была зафиксирована на отметке $7,2^{\circ} \mathrm{C}$, что отразилось как на начале вегетационного периода, так и на формировании пыльцы у деревьев груши. При этом теплые весенние месяцы и осадки способствовали продолжительному цветению и успешному оплодотворению, что явилось одним из отличий 2020 года от других годов с выраженными метеоусловиями весеннего периода, очень важными для прохождения таких фенологических фаз как цветение, оплодотворение и завязываемость плодов груши.

Приспособление к условиям культивирования носит комплексный характер и основывается на пластичности анатомических структур, изменении физиолого-биохимических параметров, пределы которых определены конкретным генотипом.

Накопленный экспериментальный и теоретический опыт свидетельствует о значимости ряда физиологических параметров, характеризующих отношение растений к засухе [21-29]. К таким характеристикам следует отнести оводненность листьев, водоудерживающую способность, остаточный водный дефицит. Экстремально высокие температуры воздуха и низкая влагообеспеченность отрицательно влияют на водный режим листового аппарата груши. Сравнительный анализ показателей водообмена листьев растений на примере данных 2005-2008 годов может служить критерием в оценке отношения генотипа к засухе (табл. 1). 
Таблица 1 - Параметры водного режима (\%) и содержания сухих веществ (мг/г) листового аппарата груши (P. communis L.) в течение летнего вегетационного периода 2005-2008 гг., (M \pm SD)

\begin{tabular}{|l|c|c|c|c|c|}
\hline \multirow{2}{*}{ Сорт } & \multicolumn{5}{|c|}{$\begin{array}{c}\text { Параметры водного режима и } \\
\text { содержание сухих веществ }\end{array}$} \\
\cline { 2 - 6 } & $\begin{array}{c}\text { Оводненность } \\
\text { листьев, \% } \\
\text { к сырой массе }\end{array}$ & $\begin{array}{c}\text { Потеря воды } \\
\text { 3а 24 часа, \% } \\
\text { к исходной } \\
\text { массе }\end{array}$ & $\begin{array}{c}\text { Водный } \\
\text { дефицит } \\
\text { листьев, } \\
\%\end{array}$ & $\begin{array}{c}\text { Сухие } \\
\text { в-ва, } \\
\text { мг/г }\end{array}$ & $\begin{array}{c}\text { Площадь } \\
\text { листа, } \\
\text { см}^{2}\end{array}$ \\
\hline \multicolumn{5}{|c|}{ Раннелетние } \\
\hline Бере Жиффар(к) & $55,35 \pm 1,15$ & $53,12 \pm 1,21$ & $4,09 \pm 1,14$ & $46,38 \pm 0,8$ & $19,73 \pm 1,5$ \\
\hline Вега & $54,51 \pm 0,86$ & $51,43 \pm 1,2$ & $2,5 \pm 0,95$ & $45,49 \pm 1,1$ & $24,9 \pm 0,7$ \\
\hline НСР 05 & 0,13 & 0,17 & 0,31 & 0,91 & 0,22 \\
\hline \multicolumn{5}{|c|}{ Летние } \\
\hline Вильямс(к) & $55,46 \pm 2,0$ & $46,64 \pm 2,2$ & $9,17 \pm 1,71$ & $37,85 \pm 1,2$ & $24,9 \pm 1,2$ \\
\hline $\begin{array}{l}\text { Черноморская } \\
\text { янтарная }\end{array}$ & $54,23 \pm 1,2$ & $52,46 \pm 1,71$ & $5,00 \pm 1,5$ & $45.76 \pm 1,0$ & $24,8 \pm 0,8$ \\
\hline НСР 05 & 0,12 & 0,11 & 0,11 & 0.81 & 0,05 \\
\hline \multicolumn{7}{|c|}{ Осенне-зимние } \\
\hline Бере Боск(к) & $55,07 \pm 2,1$ & $52,37 \pm 2,3$ & $4,67 \pm 2,12$ & $39,57 \pm 2,1$ & $29,4 \pm 1,1$ \\
\hline Рассвет & $49,26 \pm 2,15$ & $51,44 \pm 2,5$ & $2,6 \pm 2,0$ & $59,74 \pm 0,89$ & $23,81 \pm 0,75$ \\
\hline НСР 05 & 0,62 & 0,17 & 0,24 & 0,31 & 0,13 \\
\hline
\end{tabular}

Примечание: в этой таблице и последующих М-среднее арифметическое, SD-стандартная ошибка

Из таблицы 1 видно, что интродуцированные сорта в наиболее засушливый период обладали довольно большим показателем водного дефицита $(4,09-5,0$ \%), за исключением сорта Вильямс $(9,17$ \%). Анализ показателей водного режима груши позволил установить, что повышенное содержание воды в листьях сочетается со снижением водоудерживающей способности. В целом у изученных сортов разница по уровню оводненности незначительная $\left(\mathrm{HCP}_{05}=0,12-0,62\right)$, поэтому степень их засухоустойчивости в большей степени определяет величина водопотерь $\left(\mathrm{HCP}_{05}=\right.$ 0,11-0,17). Сравнение сортов груши показало, что раннелетние и летние сорта груши имеют более высокую степень оводненности, такие как Бере Жиффар $(55,35 \%)$ и Вильямс $(55,46 \%)$, следовательно, в условиях засухи у всех исследуемых сортов груши есть определенный дефицит воды.

Синтетическая активность растений характеризуется повышенным уровнем накопления сухих веществ. По этим показателям выделялись сорта 
Плодоводство и виноградарство Юга России № 72(6), 2021 г.

Рассвет (59,74 \%), Черноморская янтарная (45,76 \%), Вега (45,49 \%). При анализе относительных характеристик, определяющих эффективность растения в образовании листовой поверхности, выяснилось, что все они имеют сортовое различие, то есть определенное, имеющее тенденцию к постоянству, значение для каждого сорта, которое определяется генотипом.

Взаимосвязь продуктивности с устойчивостью сорта к основным стресс-факторам среды несомненна, однако на нее влияет и ряд других факторов, в первую очередь активность и характер работы ассимиляционного аппарата. Известно, что на силу роста, образования в растении пластических веществ, а, следовательно, на урожайность, влияет и интенсивность фотосинтеза [30, 31$]$.

Ассимиляционная активность фотосинтеза во многом определяется содержанием пигментов в листьях, а от нее, в свою очередь, зависит продуктивность растений (табл. 2).

Таблица 2 - Пигментный состав (мг/г сухого вещества) листьев груши

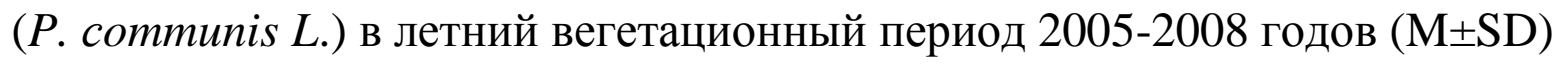

\begin{tabular}{|c|c|c|c|c|c|c|}
\hline \multirow{2}{*}{ Сорт } & \multicolumn{3}{|c|}{ Хлорофилл } & \multirow[t]{2}{*}{ Скар. } & \multirow[t]{2}{*}{$\mathrm{Ca} / \mathrm{CB}_{\mathrm{B}}$} & \multirow{2}{*}{$\frac{(\mathrm{Ca}+\mathrm{B}) /}{\text { Скар. }}$} \\
\hline & $\mathrm{a}$ & $\mathrm{b}$ & $(a+b)$ & & & \\
\hline \multicolumn{7}{|c|}{ Раннелетние } \\
\hline $\begin{array}{c}\text { Бере } \\
\text { Жиффар(к) }\end{array}$ & $1,05 \pm 0,42$ & $0,26 \pm 0,51$ & $1,31 \pm 0,41$ & $0,62 \pm 0,42$ & $4,04 \pm 0,35$ & $2,11 \pm 0,21$ \\
\hline Вега & $1,1+0,12$ & $0,43 \pm 0,22$ & $1,53 \pm 0,13$ & $0,67 \pm 0,15$ & $2,41+0,12$ & $2,3 \pm 0,15$ \\
\hline $\mathrm{HCP}_{05}$ & 0,11 & 0,24 & 0,03 & 0,03 & 0,25 & 0,02 \\
\hline \multicolumn{7}{|c|}{ Летние } \\
\hline Вильямс(к) & $0,98+0,22$ & $0,40 \pm 0,23$ & $1,38+0,22$ & $0,65 \pm 0,31$ & $2,42 \pm 0,15$ & $2,12+0,24$ \\
\hline $\begin{array}{c}\text { Черноморская } \\
\text { янтарная }\end{array}$ & $0,81 \pm 0,21$ & $0,31 \pm 0,23$ & $1,12 \pm 0,31$ & $0,40 \pm 0,32$ & $2,58 \pm 0,23$ & $2,8 \pm 0,33$ \\
\hline $\mathrm{HCP}_{05}$ & 0,12 & 0,21 & 0,11 & 0,11 & 0,09 & 0,13 \\
\hline \multicolumn{7}{|c|}{ Осенне-зимние } \\
\hline $\begin{array}{c}\text { Бере } \\
\text { Боск(к) }\end{array}$ & $0,98 \pm 0,52$ & $0,37 \pm 0,41$ & $1,35 \pm 0,37$ & $0,66 \pm 0,52$ & $1,98 \pm 0,41$ & $2,31 \pm 0,51$ \\
\hline Рассвет & $0,83 \pm 0,31$ & $0,42+0,24$ & $1,25 \pm 0,27$ & $0,54 \pm 0,32$ & $3,14 \pm 0,23$ & $2,02+0,37$ \\
\hline $\mathrm{HCP}_{05}$ & 0,15 & 0,24 & 0,08 & 0,03 & 0,09 & 0,23 \\
\hline
\end{tabular}


Основным фотосинтезирующим пигментом служит хлорофилл а. Его большое накопление в листьях характерно для сорта Вега $(1,1$ мг/г). Содержание хлорофилла $\mathrm{b}$ свидетельствует об уровне приспособленности к низкой освещенности. Чем оно больше, тем выше степень адаптации. У изученных сортов по наличию хлорофилла $\mathrm{b}$ выделились сорта Вега $(0,43$ мг/г) и Рассвет $(0,42$ мг/г). По сумме хлорофиллов также отмечен сорт Вега (1,53 мг/г). Таким образом, по содержанию хлорофиллов a, b и их сумме сорт Вега можно характеризовать как обладающий мощной пигментной системой $[3,6]$.

Гораздо более информативно количественное соотношение суммы хлорофиллов и каротина. Этот важный физиологический признак указывает на степень приспособленности растений к свету и неблагоприятным условиям среды - водного режима, температуры, минерального питания. По указанным показателям выделились сорта Вега и Рассвет (2,3 мг/г).

По отношению хлорофиллов $\mathrm{a} / \mathrm{b}$ отличились сорта Бере Жиффар (4.04 мг/г), Бере Боск (2,67 мг/г) и Черноморская Янтарная (2,58 мг/г), также этот показатель можно интерпретировать и как устойчивость пигментной системы к водному дефициту (см. табл. 1).

Анализ функциональной активности листовых пластинок показал, что достаточно высокий показатель уровня жизнеспособности $\left(\mathrm{Fm} / \mathrm{F} \_\mathrm{T}\right)$ в начале вегетационного периода и к его завершению (на примере данных 2013-2015 гг.) имели сорта Красный Вильямс (4,08-4,71), Черноморская янтарная $(4,61-3,28)$, Кильчу $(2,85-2,99)$. У интродуцированных сортов Бере Жиффар $(2,67-3,48)$ и Бере Боск $(2,15-2,67)$ фотосинтетическая активность в этот период была значительно снижена. Особенно четко проявилась способность сорта Вега к полной реализации генетического потенциала в период засухи повышением уровня жизнеспособности с 1,89 до 3,09 (табл. 3). 
Плодоводство и виноградарство Юга России № 72(6), 2021 г.

Таблица 3 - Оценка функционального состояния фотосинтетического аппарата листьев груши (Pyrus L.) в динамике развития по показателю индекса жизнеспособности $\left(\mathrm{Fm} / \mathrm{F} \_\mathrm{T}\right)$, характеризующему медленную индукцию флуоресценции хлорофилла и фотосинтетической

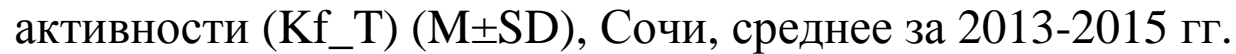

\begin{tabular}{|c|c|c|c|c|}
\hline Сорт/гибрид & Июнь & Июль & Август & Сентябрь \\
\hline \multicolumn{5}{|c|}{ Раннелетние } \\
\hline \multirow{2}{*}{$\begin{array}{ll}\text { Бере } & * \\
\text { Жиффар } & * *\end{array}$} & $2,67 \pm 0,11$ & $2,13 \pm 0,13$ & $2,43 \pm 0,12$ & $3,48 \pm 0,33$ \\
\hline & $0,66+0,02$ & $0,55+0,03$ & $0,57+0,08$ & $0,66+0,02$ \\
\hline \multirow[t]{2}{*}{ Вега } & $2,78 \pm 0,22$ & $1,89 \pm 0,13$ & $2,0 \pm 0,17$ & $3,09 \pm 0,55$ \\
\hline & $0,62 \pm 0,03$ & $0,45 \pm 0,04$ & $0,48 \pm 0,05$ & $0,68 \pm 0,01$ \\
\hline \multicolumn{5}{|c|}{ Летние } \\
\hline \multirow[t]{2}{*}{ Вильямс } & $4,03 \pm 0,1$ & $2,94 \pm 0,19$ & $2,39 \pm 0,18$ & $4,26 \pm 0,4$ \\
\hline & $0,75 \pm 0,006$ & $0,65 \pm 0,027$ & $0,57 \pm 0,03$ & $0,78 \pm 0,05$ \\
\hline \multirow{2}{*}{$\begin{array}{l}\text { Черноморская } \\
\text { янтарная }\end{array}$} & $4,61 \pm 0,20$ & $2,51 \pm 0,11$ & $2,7 \pm 0,09$ & $3,28 \pm 0,11$ \\
\hline & $0,78 \pm 0,09$ & $0,59 \pm 0,08$ & $0,63 \pm 0,01$ & $0,71 \pm 0,03$ \\
\hline \multirow[t]{2}{*}{ Красный Вильямс } & $4,08 \pm 0,13$ & $3,37 \pm 0,06$ & $3,22 \pm 0,18$ & $4,71 \pm 0,52$ \\
\hline & $0,75 \pm 0,008$ & $0,70 \pm 0,007$ & $0,68 \pm 0,02$ & $0,69 \pm 0,009$ \\
\hline \multicolumn{5}{|c|}{ Осенне-зимние } \\
\hline \multirow{2}{*}{$\begin{array}{l}\text { Бере } \\
\text { Боск }\end{array}$} & $2,15 \pm 0,1$ & $1,95 \pm 0,1$ & $2,37 \pm 0,07$ & $3,14 \pm 0,25$ \\
\hline & $0,53 \pm 0,022$ & $0,48 \pm 0,02$ & $0,57 \pm 0,01$ & $0,62 \pm 0,03$ \\
\hline \multirow[t]{2}{*}{ Рассвет } & $2,58 \pm 0,13$ & $2,37 \pm 0,08$ & $2,5 \pm 0,17$ & $3,41 \pm 0,23$ \\
\hline & $0,61 \pm 0,02$ & $0,51 \pm 0,03$ & $0,58 \pm 0,02$ & $0,76 \pm 0,14$ \\
\hline \multirow{2}{*}{$\begin{array}{l}\text { Гибрид } \\
\text { № } 8520\end{array}$} & $3,07 \pm 0,15$ & $3,06 \pm 0,15$ & $2,56 \pm 0,311$ & $3,44 \pm 0,21$ \\
\hline & $0,67 \pm 0,017$ & $0,55+0,03$ & $0,57 \pm 0,08$ & $0,69 \pm 0,02$ \\
\hline \multirow[t]{2}{*}{ Кильчу ${ }^{x}$} & $2,85 \pm 0,03$ & $2,51 \pm 0,08$ & $2,39 \pm 0,06$ & $2,99 \pm 0,33$ \\
\hline & $0,63 \pm 0,03$ & $0,60 \pm 0,013$ & $0,59 \pm 0,03$ & $0,61 \pm 0,02$ \\
\hline
\end{tabular}

Примечание: *-Fm/F_T; **-Kf_T. Все изучаемые сортообразцы - P.communis; ${ }^{x_{-}}$Pyrus pyrifolia

Таким образом, в процессе роста и развития груши фотосинтетическая функция листьев непрерывно корректируется, обусловливая связь продуктивности и жизнеспособности растений с интенсивностью фотосинтеза в листьях.

Физиологическое состояние растений, фотосинтетическая функция существенно связаны с увеличением площади листовой пластинки, так по результатам наших исследований линейные параметры листа в течение вегетационного периода зависели от генотипа и гидротермических условий года. 
Анализ изменений толщины листа, соотношения тканей мезофилла, а также размеров клеток столбчатой и губчатой паренхимы на протяжении вегетации оценивает по этим показателям сорта, отличающиеся различной стойкостью к засухе. Так, по площади листовой пластинки на протяжении всего периода вегетации выделяется сорт Красный Вильямс, имеющий характерную ксероморфную структуру листа $\left(17,24 \mathrm{~cm}^{2}\right)$, а у сорта Бере Боск $\left(33,4\right.$ см$\left.^{2}\right)$ наблюдается сильная зависимость от климатических факторов [1]. Сорт Бере Жиффар характеризуется уменьшением площади листовой пластинки в наиболее засушливый период, в среднем составляющей 19,7 см² $^{2}$ У остальных сортов изменения в размере листа незначительны $[3,6,12,14,16]$.

Склерофильность - масса единицы площади, которая, как и её составляющие, меняется под воздействием света, влажности и других экологических факторов [32]. Степень склерофильности листьев определяется как отношение сухой массы листьев к их площади. Удельная масса (масса единицы площади) листовых пластинок увеличивается с ростом дефицита влаги $(\mathrm{r}=0,97)$. Эти изменения мы связываем с адаптацией к стрессу. Несоответствие параметров листовых пластинок уровню негативного воздействия может означать, что при сильной стрессовой нагрузке адаптивные возможности данных генотипов были истощены. Так, в 2014 году сорта Вега (-1,44 от ср. многолетн.), Черноморская янтарная $(-2,4)$ и Рассвет $(-10,01)$ показали снижение уровня удельной массы листовых пластинок по сравнению со средними многолетними данными, что связано с обильным количеством осадков $(\mathrm{r}=-0,89)$. Сорта Бере Жиффар и Бере Боск демонстрируют уровень удельной массы листовых пластинок примерно равный в условиях 2013 г. уровню 2004-2012 гг., что подтверждает нормальное физиологическое состояние данных генотипов в период благоприятных погодных условий [32, 33]. 
Плодоводство и виноградарство Юга России № 72(6), 2021 г.

Изменения физиологических процессов влияют на анатомомофологическое строение листа. Лист груши дорзовентрального типа, мезофилл дифференцирован на палисадную и столбчатую ткани. Палисадная ткань состоит из двух слоев клеток. Устьичный аппарат аномоцитного типа, устьица сосредоточены на абаксиальной стороне листовых пластинок. Полученные физиологические данные частично соотносятся с морфо-анатомическими особенностями эпидермальной ткани листьев соответствующих генотипов [3, 12, 28, 30, 34]. Так, при сильной стрессовой нагрузке, адаптивные возможности растений истощаются. В то же время наблюдается изменение соотношения различных слоев паренхимы листа и анатомического строения листа груши в целом [3, 6, 12, 30]. Индекс палисадности (соотношение толщины палисадного и губчатого слоев) - наиболее информативен как показатель устойчивости к засухе [3]. Чем индекс (ИП) выше, тем сорт устойчивее к засухе. Сорта Вега, Красный Вильямс, Славянка, Вербена, Бере Боск имеют достаточно высокий индекс от 0,13 (Вербена) до 0,35 (Бере Боск) (табл. 4).

Таблица 4 - Сравнительная характеристика анатомо-морфологических показателей листовой пластинки у генотипов груши (Pyrus L.)

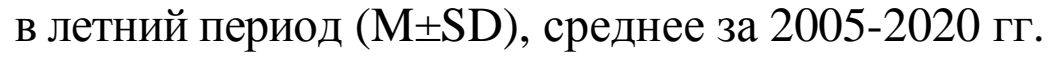

\begin{tabular}{|l|c|c|c|}
\hline \multicolumn{1}{|c|}{ Сорт/гибрид } & $\begin{array}{c}\text { Общая толщина } \\
\text { листовой пластинки, } \\
\text { мкм }\end{array}$ & $\begin{array}{c}\text { Кутикула с верхним } \\
\text { эпидермисом, } \\
\text { мкм }\end{array}$ & $\begin{array}{c}\text { Индекс } \\
\text { палисадности }\end{array}$ \\
\hline Бере Жиффар & $45,8 \pm 2,12$ & $1,24 \pm 0,12$ & $0,08 \pm 0,03$ \\
\hline Вега & $54,84 \pm 1,7$ & $2,02 \pm 0,01$ & $0,15 \pm 0,02$ \\
\hline Вильямс & $48,84 \pm 1,5$ & $1,5 \pm 0,21$ & $0,11 \pm 0,02$ \\
\hline Красный Вильямс & $42,94 \pm 1,2$ & $1,96 \pm 0,2$ & $0,17 \pm 0,01$ \\
\hline Черноморская янтарная & $67,24 \pm 2,1$ & $2,1 \pm 0,17$ & $0,08 \pm 0,02$ \\
\hline Южанка & $48,82 \pm 3,0$ & $1,5 \pm 0,41$ & $0,12 \pm 0,03$ \\
\hline Нектарная & $60,92 \pm 3,2$ & $1,5 \pm 0,32$ & $0,11 \pm 0,03$ \\
\hline Славянка & $51,88 \pm 2,8$ & $2,0 \pm 0,31$ & $0,15 \pm 0,03$ \\
\hline Вербена & $34,04 \pm 0,52$ & $1,42 \pm 0,12$ & $0,13 \pm 0,01$ \\
\hline Лучистая & $49,12 \pm 1,7$ & $2,28 \pm 0,21$ & $0,12 \pm 0,02$ \\
\hline Бере Боск & $36,98 \pm 2,0$ & $2,3 \pm 1,0$ & $0,35 \pm 0,02$ \\
\hline № 8520 & $57,02 \pm 2,1$ & $2,38 \pm 0,22$ & $0,07 \pm 0,02$ \\
\hline Рассвет & $42,68 \pm 1,2$ & $1,94 \pm 0,12$ & $0,17 \pm 0,01$ \\
\hline Кильчу & $61,02 \pm 1,3$ & $1,5 \pm 0,21$ & $0,11 \pm 0,02$ \\
\hline НСР 05 & 4,13 & 0,79 & 0,27 \\
\hline
\end{tabular}


Плодоводство и виноградарство Юга России № 72(6), 2021 г.

Определено, что повышенные температуры при отсутствии осадков способствуют значительному увеличению толщины палисадной паренхимы (до $60 \%$,) основная функция которой фотосинтез. При увеличении содержания общей влаги в листьях ростовых побегов развита рыхлая губчатая ткань, основная функция которой газообмен и транспирация. В засушливый период практически у всех генотипов проявлялись ксероморфные признаки, обусловливающие засухоустойчивость: увеличение толщины листовой пластинки, кутикулы, индекса палисадности, числа устьиц на единицу листовой поверхности, уменьшение размеров устьиц и коэффициента потенциальной транспирационной поверхности (табл. 5 и 6).

Таблица 5 - Характеристика устьичного аппарата (число устьиц, шт. и размеры замыкающих клеток, мкм) груши (Pyrus L.)

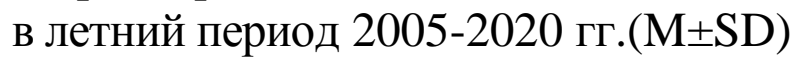

\begin{tabular}{|c|c|c|c|c|}
\hline \multirow[b]{2}{*}{ Сорт/гибрид } & \multicolumn{3}{|c|}{ Параметры листовой пластинки (мкм) } & \multirow{2}{*}{$\begin{array}{c}\text { Коэффициент } \\
\text { потенциальной } \\
\text { транспирационной } \\
\text { поверхности } \\
\text { (КПТП) } \\
\end{array}$} \\
\hline & $\begin{array}{c}\text { длина, } \\
\text { мкм }\end{array}$ & $\begin{array}{c}\text { ширина, } \\
\text { мкм }\end{array}$ & $\begin{array}{c}\text { количество } \\
\text { устьиц } \\
\text { на } 1 \text { мм }^{2}, \\
\text { шт. }\end{array}$ & \\
\hline Бере Жиффар & $106,06 \pm 0,84$ & $63,6 \pm 0,54$ & $200 \pm 1,12$ & $21212 \pm 0,12$ \\
\hline Вега & $106,02 \pm 0,2$ & $63,6 \pm 0,42$ & $320 \pm 1,2$ & $33926.4 \pm 0,01$ \\
\hline Вильямс & $116,86 \pm 1,2$ & $79,5 \pm 0,55$ & $280 \pm 1,1$ & $32720.8 \pm 0,5$ \\
\hline Красный Вильямс & $62,1 \pm 1,35$ & $71,5 \pm 0,47$ & $280 \pm 0,7$ & $17388 \pm 0,1$ \\
\hline Черноморская янтарная & $87,2 \pm 0,31$ & $79,5 \pm 0,41$ & $200 \pm 1,2$ & $17440 \pm 0,05$ \\
\hline Южанка & $90,08 \pm 0,42$ & $63,6 \pm 0,62$ & $620 \pm 1,3$ & $55849.6 \pm 1,2$ \\
\hline Нектарная & $90,01 \pm 0,51$ & $63,6 \pm 0,55$ & $280 \pm 1,2$ & $25202.8 \pm 1,2$ \\
\hline Славянка & $105,9 \pm 0,51$ & $63,6 \pm 0,52$ & $320 \pm 1,0$ & $33888 \pm 1,1$ \\
\hline Вербена & $109,0 \pm 0,21$ & $74,2 \pm 0,42$ & $640 \pm 0,5$ & $69760 \pm 0,3$ \\
\hline Лучистая & $106,2 \pm 0,41$ & $71,5 \pm 0,51$ & $600 \pm 1,0$ & $63720 \pm 1,0$ \\
\hline Бере Боск & $62,1 \pm 0,81$ & $72,4 \pm 0,62$ & $320 \pm 2,1$ & $19872 \pm 1,2$ \\
\hline № 8520 & $116,2+0,41$ & $79,5 \pm 0,44$ & $200 \pm 0,2$ & $23240 \pm 0,5$ \\
\hline Рассвет & $111,36+0,32$ & $76,8 \pm 0,42$ & $520 \pm 0,2$ & $57907.2 \pm 0,1$ \\
\hline Кильчу & $119,9 \pm 0,34$ & $70,6 \pm 0,62$ & $560 \pm 1,1$ & $67144 \pm 1,0$ \\
\hline $\mathrm{HCP}_{05}$ & 3,33 & 5,1 & 4,21 & 5,23 \\
\hline
\end{tabular}

Коэффициент потенциальной транспирационной поверхности - произведение длины замыкающих клеток устьиц и их количество на 1 мм² листовой поверхности (Папихин, 2011) [35]. Сорта Вега, Вильямс, Южанка, 
Рассвет, Вербена, Славянка, Лучистая, Кильчу с большим коэффициентом потенциальной транспирационной поверхности имеют более ксероморфную структуру листа с расширенной возможностью регуляции испарения влаги.

По величине устьиц выделялись сорт Кильчу восточно-азиатской группы (P. pyrifolia R.) и районированные сорта нашей зоны Вега, Рассвет, Вербена. Бере Боск (осенне-зимний) и Вега (раннелетний) отличались самыми мелкими клетками верхнего и нижнего эпидермиса. Все сорта вида P. communis характеризовались извилистой, с крупными зигзагами формой стенок клеток нижнего эпидермиса, наименьшее количествое устьиц на 1 мм² листовой поверхности определено у летних сортов Вега и Черноморская янтарная. Наши исследования показали, что изучение анатомических особенностей эпидермиса листа действительно имеет большое значение для установления происхождения отдельных сортовых групп груши. У груши признаки количества и величины устьиц не связаны ни с географическим распространением сорта, ни со сроками созревания плодов. Однако у культурных сортов количество и величина устьиц определяется особенностями одного или нескольких видов, от которых произошла та или иная группа сортов. Таким образом, количественно-анатомические признаки эпидермиса могут служить дополнительными данными при классификации сортов груши. Так, корейский сорт Кильчу восточно-азиатской группы имеет эпидермис с очень извилистыми клетками, а европейские сорта и P. communis включают формы с простыми очертаниями клеток, овальными, или слегка угловатыми, слабоизвилистыми.

Г.Н. Еремеев установил наличие тесной связи засухоустойчивости плодовых растений с водоудерживающей способностью их листьев [36]. Устойчивые к засухе сорта характеризуются высокой водоудерживающей способностью. Возможность сорта удерживать и экономно расходовать воду в засушливых условиях является защитно-приспособительной реакцией устойчивых растений $[2,3,4,6,8,12,15,16]$. В результате математи- 
ческой обработки получены коэффициенты ранговой корреляции между водоудерживающей способностью листьев и анатомическими признаками: толщиной поперечного среза листовой пластинки и числом устьиц исследуемых шести сортов груши. Определено, что способность листовой пластинки удерживать воду в течение двадцати четырех часов у всех сортов груши имеет высокую обратную зависимость от числа устьиц на нижнем эпидермисе листа $r=-0,77$, при этом показатель остаточного водного дефицита с этим анатомическим признаком имеет среднюю обратную зависимость $r=-0,26$, а водоудерживающая способность напрямую зависит от толщины поперечного среза листовой пластинки $(r=0,32)[3,6,12]$.

Bbыводы. Анализ полученных данных показал, что наиболее адаптивными и устойчивыми к засухе по комплексу вышеперечисленных признаков в сравнении с контролем оказались сорта Красный Вильямс, Черноморская янтарная, Вега и Рассвет. Определено, что влияние стрессовых погодных условий приводит к появлению у генотипа таких ксероморфных признаков, как усиленное развитие слоя палисадной паренхимы и уменьшение количества устьиц на единицу поверхности. Увеличение площади листовой пластинки и снижение содержания сухих веществ свидетельствуют о более эффективном использовании продуктов фотосинтеза, что согласуется с большим содержанием свободной воды в листьях. Выявлено, что при благоприятных погодных условиях наблюдается увеличение толщины листовой пластинки при изменении соотношения слоев паренхимы листа и анатомического строения в целом.

\section{Литература}

1. Жученко, А.А. Адаптивное растениеводство. Кишинев: Штиинца, 1990.

2. Ерёмин Г.В., Гасанова Т.А. Изучение жаростойкости и засухоустойчивости сортов // Программа и методика сортоизучения плодовых, ягодных и орехоплодных культур / под ред. Е.Н. Седова, Т.П. Огольцовой. Орел: ВНИИСПК, 1999. С. 80-85. 
3. Киселева, Н.С. Оценка адаптационной способности различных генотипов груши по морфо-анатомическому и физиологическому состоянию листьев // Сельскохозяйственная биология. 2009. № 3. С. 34-38.

4. Кушниренко М.Д., Печерская С.Н. Физиология водообмена и засухоустойчивости растений. Кишинев: Штиинца, 1991. 306 с.

5. Еремин Г.В., Гасанова Т.А. Специфические проявления абиотических стрессов у плодовых растений на юге России и возможности минимизации их последствий [Электронный ресурс] // Плодоводство и виноградарство Юга России. 2011. № 12(6). C. 1-11. URL: http://journalkubansad.ru/pdf/11/06/01.pdf. (дата обращения: 11.11.2021).

6. Киселева Н.С. Оценка адаптационного потенциала различных генотипов груши к стресс-факторам внешней среды // Плодоводство и ягодоводство России. 2014. T. 38. № 1. C. 187-193.

7. Программа и методика сортоизучения плодовых, ягодных и орехоплодных культур. Орел: ВНИИСПК, 1999. 608 с.

8. Программа Северо-Кавказского центра по селекции плодовых, ягодных, цветочно-декоративных культур и винограда на период до 2030 года / Под ред. Е.А. Егорова. Краснодар: СКЗНИИСиВ, 2013. 202 с.

9. Воронин, Н.С. Руководство к лабораторным занятиям по анатомии и морфологии растений. Учебн. пос.: изд. 2-е, перераб. М.: Просвещение, 1972. 160 с.

10. Современные инструментально-аналитические методы исследования плодовых культур и винограда / Н.И. Ненько, И.А. Ильина, Т.Н. Воробьева [и др.]; под общ. ред. Н.И. Ненько. Краснодар: СКЗНИИСиВ, 2015. 115 с.

11. Функциональная активность листового аппарата яблони при воздействии стрессоров летнего периода / Н.И. Ненько [и др.] // Научные труды СКФНЦСВВ. Т. 28. Краснодар: ФГБНУ СКФНЦСВВ, 2020. C. 30-37. https://elibrary.ru DOI: 10.30679/25879847-2020-28-30-37.

12. Киселева Н.С. Адаптационные механизмы приспособления различных генотипов груши к условиям стресс-факторов внешней среды // Культурные растения для устойчивого сельского хозяйства в XXI веке (иммунитет, селекция, интродукция) / Под ред. И. М. Куликова. М., 2011. Т. IV, ч. II. С. 489-493.

13. Ульяновская Е.В., Супрун И.И., Токмаков С.В., Ушакова Я.В. Комплексный подход к отбору ценных генотипов яблони, устойчивых к стрессовым факторам среды [Электронный ресурс] // Плодоводство и виноградарство Юга России. 2014. № 25(1). C. 11-25. URL: http://journalkubansad.ru/pdf/14/01/02.pdf. (дата обращения: 11.11.2021).

14. Ненько Н.И., Ильина И.А., Петров В.С., Сундырева М.А. Физиологобиохимические методы изучения исходного и селекционного материала // Современные методологические аспекты организации селекционного процесса в садоводстве и виноградарстве. Краснодар: СКЗНИИСиВ, 2012. С. 530-540.

15. Можар Н.В. Поиск засухоустойчивых сортов груши для условий Центральной зоны Краснодарского края // Научные труды ГНУ СКЗНИИСиВ. Т. 5. Краснодар: СКЗНИИСиВ, 2014. С. 39-44.

16. Панфилова О.В., Голяева О.Д. Физиологические особенности адаптации сортов и отборных форм смородины красной к засухе и повышенным температурам // Сельскохозяйственная биология. 2017. № 52 (5). С. 1056-1064 (doi: 10.15389/ agrobiology.2017.5.1056rus).

17. Weather [Electronic resource]. Mode of the access - http://www.pogodaiklimat.ru/ [Date of the address: 11.06.2019]. [in Russian] (Погода. [Электронный ресурс] Режим доступа - http://www.pogodaiklimat.ru/ [дата обращения: 11.06.2019]. 
18. Будаковская О.Н. Новые оптические методы и приборы количественной оценки адаптивного потенциала садовых растений // Плодоводство и ягодоводство России. 2011. Т. 27 (1). С. $74-79$.

19. Климов С.В. Спонтанная осцилляция замедленной флуоресценции при диагностике устойчивости сельскохозяйственных растений к неблагоприятным факторам внешней среды // Сельскохозяйственная биология. 1996. № 5. С. 115-122.

20. Лакин, Г.Ф. Биометрия: Учеб. пособ. Для биол. спец. вузов. 4-е изд. М.: Высшая школа, 1990. 352 с.

21. F. Xiao, Z.Q. Yang, K.W., Lee J. Photosynthetic and physiological responses to high temperature in grapevine (Vitis vinifera L.) leaves during the seedling stage // Hortic. Sci. Biotechnol. 2017. V. 92(1). P. 2-10 http://doi.org/10.1080/14620316. 2016.1211493.

22. Chen K., Li G.J., Bressan R.A., Song C.P., Zhu J.K., Zha Y. Abscisic acid dynamics, signaling, and functions in plants // Journal of Integrative Plant Biology. 2020. № 62(1). P. 25-54 doi:10.1111/jipb.12899

23. Vishwakarma K., Upadhyay N., Kumar N., Yadav G., Singh J., Mishra R.K., Kumar V., Verma R., Upadhyay R.G., Pandey M. et al. Abscisic acid signaling and abiotic stress tolerance in plants: A review on current knowledge and future prospects // Front Plant Sci. 2017. № 8. P.161/ URL: https://doi.org/10.3389/fpls.2017.00161

24. Šircelj H., Tausz M., Grill D., Batič F. Detecting different levels of drought stress in apple trees (Malus domestica Borkh.) with selected biochemical and physiological parameters. Scientia Horticulturae, 2007. V.113(4). P. 362-369 (doi: 10.1016/ j. scienta. 2007.04.012).

25. Meng Q.-J., Wang G.-Q., Dong S.-F., Zhang L., Gong Z.-D. Relation between leaf tissue parameters and drought resistance of peaches. Agricultural Research in the Arid Areas, 2004. № 22(3). P. 123-126.

26. Mierowska A., Keutgen N., Huysamer M., Smith V. Photosynthetic acclimation of apples spur leaves to summer-pruning. Scientia Horticulturae, 2002. № 92(1). P. 9-27 (doi: 10.1016/S0304-4238(01)00275-8).

27. Wang S., Liang D., Li C., Hao Y., Ma F., Shu H. Influence of drought stress on the cellular ultrastructure and antioxidant system in leaves of drought-tolerant and droughtsensitive apple rootstocks. Plant Physiol. Biochem., 2012. № 51. P.81-89 (doi: 10.1016/j.plaphy.2011.10.014).

28. Nenko N.I., Kiseleva G.K., Ulyanovskaya E.V., Yablonskay E.K., Karavaeva A.V. Physiological - biochemical criteria of the apple-tree resistance to the summer period abiotic stresses // EurAsian Journal of Biosciences. 2018. V.12 (1). P. 55-61.

29. Yadollahi A., Arzani K., Ebadi A., Wirthensohn M., Karimi S. The response of different almond genotypes to moderate and severe water stress in order to screen for drought tolerance. Scientia Horticulturae, 2011. V.129(3). P.403-413 (doi: 10.1016/j.scienta.2011.04.007).

30. Ненько Н.И., Киселева Г.К., Ульяновская Е.В., Караваева А.В., Схаляхо Т.В. Водный обмен и пигментный состав листьев яблони в связи с засухой [Электронный ресурс] // Плодоводство и виноградарство Юга России. 2021. № 69(3). C. 123-137. URL: http://journalkubansad.ru/pdf/21/03/10.pdf. DOI: 10.30679/2219-53352021-3-69-123-137 (дата обращения: 15.09.2021).

31. Апкарова М.Р. Физиологические аспекты устойчивости груши к стрессфакторам и продуктивность сортов с разным сроком созревания плодов : дис. ... канд. биол. наук : 06.01.05 / Апкарова Мария Романовна. Краснодар, 2006. 180 с. 
32. Киселева, Н.С. Оценка изменчивости степени склерофильности листовых пластинок груши // Вестник российской сельскохозяйственной науки. 2016. Т. 1. № 1. C. 34-36. URL: https://www.vestnik-rsn.ru/vrsn/article/view/206. (Дата доступа: 01 июнь 2021).

33. Хвостова И.В., Апкарова М.Р., Можар Н.В. Анализ адаптивного потенциала груши различных сроков созревания // Организационно-экономический механизм инновационного процесса и приоритетные проблемы научного обеспечения развития отрасли: материалы науч.-практ. конф. (Краснодар, 3-4 февр. 2003 г.). Краснодар: СКЗНИИСиВ. Краснодар, 2003. С. 174-178.

34. Massonnet C., Costes E., Rambal S., Dreyer E., Regnard J.L. Stomatal regulation of photosynthesis in apple leaves: evidence for different water-use strategies between two cultivars. Annals of Botany, 2007, 100(6): 1347-1356 (doi: 10.1093/aob/mcm222).

35. Папихин Р.В., Дубровский М.Л., Кружков А.В. Цитоанатомический анализ устьиц у сортов и форм абрикоса для оценки потенциала засухоустойчивости // Плодоводство и ягодоводство России. 2011. Т. XXVIII. Ч. 2. С. 123-129.

36. Еремеев, Г.Н. Лабораторно-полевой метод оценки засухоустойчивости плодовых и др. растений и краткие результаты его применения // Труды Никитского ботанического сада. 1964. Т. 37. С. 472-488.

\section{Reference}

1. Zhuchenko, A.A. Adaptivnoe rastenievodstvo. Kishinev: «Shtiinca», 1990.

2. Eryomin G.V., Gasanova T.A. Izuchenie zharostojkosti i zasuhoustojchivosti sortov // Programma i metodika sortoizucheniya plodovyh, yagodnyh i orekhoplodnyh kul'tur / pod red. E.N. Sedova, T.P. Ogol'covoj. Orel: VNIISPK, 1999. S. 80-85.

3. Kiseleva, N.S. Ocenka adaptacionnoj sposobnosti razlichnyh genotipov grushi po morfo-anatomicheskomu i fiziologicheskomu sostoyaniyu list'ev // Sel'skohozyajstvennaya biologiya. 2009. № 3. S. 34-38.

4. Kushnirenko M.D., Pecherskaya S.N. Fiziologiya vodoobmena i zasuhoustojchivosti rastenij. Kishinev: Shtiinca, 1991. $306 \mathrm{~s}$.

5. Eremin G.V., Gasanova T.A. Specificheskie proyavleniya abioticheskih stresssov u plodovyh rastenij na yuge Rossii i vozmozhnosti minimizacii ih posledstvij [Elektronnyj resurs] // Plodovodstvo i vinogradarstvo Yuga Rossii. 2011. № 12(6). S. 1-11. URL: http://journalkubansad.ru/pdf/11/06/01.pdf. (data obrashcheniya: 11.11.2021).

6. Kiseleva N.S. Ocenka adaptacionnogo potenciala razlichnyh genotipov grushi $\mathrm{k}$ stress-faktoram vneshnej sredy // Plodovodstvo i yagodovodstvo Rossii. 2014. T. 38. № 1. S. 187-193.

7. Programma i metodika sortoizucheniya plodovyh, yagodnyh i orekhoplodnyh kul'tur. Orel: VNIISPK, 1999. $608 \mathrm{s.}$

8. Programma Severo-Kavkazskogo centra po selekcii plodovyh, yagodnyh, cvetochno-dekorativnyh kul'tur i vinograda na period do 2030 goda / Pod red. E.A. Egorova. Krasnodar: SKZNIISiV, 2013. 202 s.

9. Voronin, N.S. Rukovodstvo k laboratornym zanyatiyam po anatomii i morfologii rastenij. Uchebn. pos.: izd. 2-e, pererab. M.: Prosveshchenie, 1972. $160 \mathrm{s.}$

10. Sovremennye instrumental'no-analiticheskie metody issledovaniya plodovyh kul'tur i vinograda / N.I. Nen'ko, I.A. Il'ina, T.N. Vorob'eva [i dr.]; pod obshch. red. N.I. Nen'ko. Krasnodar: SKZNIISiV, 2015. 115 s.

11. Funkcional'naya aktivnost' listovogo apparata yabloni pri vozdejstvii stressorov letnego perioda / N.I. Nen'ko [i dr.] // Nauchnye trudy SKFNCSVV. T. 28. Krasnodar: FGBNU SKFNCSVV, 2020. S. 30-37. https://elibrary.ru DOI: 10.30679/2587-9847-2020-2830-37. 
12. Kiseleva N.S. Adaptacionnye mekhanizmy prisposobleniya razlichnyh genotipov grushi k usloviyam stress-faktorov vneshnej sredy // Kul'turnye rasteniya dlya ustojchivogo sel'skogo hozyajstva v XXI veke (immunitet, selekciya, introdukciya) / Pod red. I. M. Kulikova. M., 2011. T. IV, ch. II. S. 489-493.

13. Ul'yanovskaya E.V., Suprun I.I., Tokmakov S.V., Ushakova Ya.V. Kompleksnyj podhod k otboru cennyh genotipov yabloni, ustojchivyh $\mathrm{k}$ stressovym faktoram sredy [Elektronnyj resurs] // Plodovodstvo i vinogradarstvo Yuga Rossii. 2014. № 25(1). S. 11-25. URL: http://journalkubansad.ru/pdf/14/01/02.pdf. (data obrashcheniya: 11.11.2021).

14. Nen'ko N.I., Il'ina I.A., Petrov V.S., Sundyreva M.A. Fiziologo-biohimicheskie metody izucheniya iskhodnogo i selekcionnogo materiala // Sovremennye metodologicheskie aspekty organizacii selekcionnogo processa $\mathrm{v}$ sadovodstve i vinogradarstve. Krasnodar: SKZNIISiV, 2012. S. 530-540.

15. Mozhar N.V. Poisk zasuhoustojchivyh sortov grushi dlya uslovij Central'noj zony Krasnodarskogo kraya // Nauchnye trudy GNU SKZNIISiV. T. 5. Krasnodar: SKZNIISiV, 2014. S. 39-44.

16. Panfilova O.V., Golyaeva O.D. Fiziologicheskie osobennosti adaptacii sortov i otbornyh form smorodiny krasnoj $\mathrm{k}$ zasuhe i povyshennym temperaturam // Sel'skohozyajstvennaya biologiya. 2017. № 52 (5). S. 1056-1064 (doi: 10.15389/ agrobiology.2017.5.1056rus).

17. Weather [Electronic resource]. Mode of the access - http://www.pogodaiklimat.ru/ [Date of the address: 11.06.2019]. [in Russian] (Pogoda. [Elektronnyj resurs] Rezhim dostupa - http://www.pogodaiklimat.ru/ [data obrashcheniya: 11.06.2019].

18. Budakovskaya O.N. Novye opticheskie metody i pribory kolichestvennoj ocenki adaptivnogo potenciala sadovyh rastenij // Plodovodstvo i yagodovodstvo Rossii. 2011. T. 27 (1). S. 74-79.

19. Klimov S.V. Spontannaya oscillyaciya zamedlennoj fluorescencii pri diagnostike ustojchivosti sel'skohozyajstvennyh rastenij k neblagopriyatnym faktoram vneshnej sredy // Sel'skohozyajstvennaya biologiya. 1996. № 5. S. 115-122.

20. Lakin, G.F. Biometriya: Ucheb. posob. Dlya biol. spec. vuzov. 4-e izd. M.: Vysshaya shkola, 1990. 352 s.

21. F. Xiao, Z.Q. Yang, K.W., Lee J. Photosynthetic and physiological responses to high temperature in grapevine (Vitis vinifera L.) leaves during the seedling stage // Hortic. Sci. Biotechnol. 2017. V. 92(1). P. 2-10 http://doi.org/10.1080/14620316. 2016.1211493.

22. Chen K., Li G.J., Bressan R.A., Song C.P., Zhu J.K., Zha Y. Abscisic acid dynamics, signaling, and functions in plants // Journal of Integrative Plant Biology. 2020. № 62(1). P. 25-54 doi:10.1111/jipb.12899

23. Vishwakarma K., Upadhyay N., Kumar N., Yadav G., Singh J., Mishra R.K., Kumar V., Verma R., Upadhyay R.G., Pandey M. et al. Abscisic acid signaling and abiotic stress tolerance in plants: A review on current knowledge and future prospects // Front Plant Sci. 2017. № 8. P.161/ URL: https://doi.org/10.3389/fpls.2017.00161

24. Šircelj H., Tausz M., Grill D., Batič F. Detecting different levels of drought stress in apple trees (Malus domestica Borkh.) with selected biochemical and physiological parameters. Scientia Horticulturae, 2007. V.113(4). P. 362-369 (doi: 10.1016/ j. scienta. 2007.04.012).

25. Meng Q.-J., Wang G.-Q., Dong S.-F., Zhang L., Gong Z.-D. Relation between leaf tissue parameters and drought resistance of peaches. Agricultural Research in the Arid Areas, 2004. № 22(3). P. 123-126. 
26. Mierowska A., Keutgen N., Huysamer M., Smith V. Photosynthetic acclimation of apples spur leaves to summer-pruning. Scientia Horticulturae, 2002. № 92(1). P. 9-27 (doi: 10.1016/S0304-4238(01)00275-8).

27. Wang S., Liang D., Li C., Hao Y., Ma F., Shu H. Influence of drought stress on the cellular ultrastructure and antioxidant system in leaves of drought-tolerant and droughtsensitive apple rootstocks. Plant Physiol. Biochem., 2012. № 51. P.81-89 (doi: 10.1016/j.plaphy.2011.10.014).

28. Nenko N.I., Kiseleva G.K., Ulyanovskaya E.V., Yablonskay E.K., Karavaeva A.V. Physiological - biochemical criteria of the apple-tree resistance to the summer period abiotic stresses // EurAsian Journal of Biosciences. 2018. V.12 (1). P. 55-61.

29. Yadollahi A., Arzani K., Ebadi A., Wirthensohn M., Karimi S. The response of different almond genotypes to moderate and severe water stress in order to screen for drought tolerance. Scientia Horticulturae, 2011. V.129(3). P.403-413 (doi: 10.1016/j.scienta.2011.04.007).

30. Nen'ko N.I., Kiseleva G.K., Ul'yanovskaya E.V., Karavaeva A.V., Skhalyaho T.V. Vodnyj obmen i pigmentnyj sostav list'ev yabloni v svyazi s zasuhoj [Elektronnyj resurs] // Plodovodstvo i vinogradarstvo Yuga Rossii. 2021. № 69(3). S. 123-137. URL: http://journalkubansad.ru/pdf/21/03/10.pdf. DOI: 10.30679/2219-5335-2021-3-69-123-137 (data obrashcheniya: 15.09.2021).

31. Apkarova M.R. Fiziologicheskie aspekty ustojchivosti grushi k stress-faktoram i produktivnost' sortov s raznym srokom sozrevaniya plodov : dis. ... kand. biol. nauk : 06.01.05 / Apkarova Mariya Romanovna. Krasnodar, 2006. $180 \mathrm{~s}$.

32. Kiseleva, N.S. Ocenka izmenchivosti stepeni sklerofil'nosti listovyh plastinok grushi // Vestnik rossijskoj sel'skohozyajstvennoj nauki. 2016. T. 1. № 1. S. 34-36. URL: https://www.vestnik-rsn.ru/vrsn/article/view/206. (Data dostupa: 01 iyun' 2021).

33. Hvostova I.V., Apkarova M.R., Mozhar N.V. Analiz adaptivnogo potenciala grushi razlichnyh srokov sozrevaniya // Organizacionno-ekonomicheskij mekhanizm innovacionnogo processa i prioritetnye problemy nauchnogo obespecheniya razvitiya otrasli: materialy nauch.-prakt. konf. (Krasnodar, 3-4 fevr. 2003 g.). Krasnodar: SKZNIISiV. Krasnodar, 2003. S. 174-178.

34. Massonnet C., Costes E., Rambal S., Dreyer E., Regnard J.L. Stomatal regulation of photosynthesis in apple leaves: evidence for different water-use strategies between two cultivars. Annals of Botany, 2007, 100(6): 1347-1356 (doi: 10.1093/aob/mcm222).

35. Papihin R.V., Dubrovskij M.L., Kruzhkov A.V. Citoanatomicheskij analiz ust'ic u sortov i form abrikosa dlya ocenki potenciala zasuhoustojchivosti // Plodovodstvo i yagodovodstvo Rossii. 2011. T. XXVIII. Ch. 2. S. 123-129.

36. Eremeev, G.N. Laboratorno-polevoj metod ocenki zasuhoustojchivosti plodovyh i dr. rastenij i kratkie rezul'taty ego primeneniya // Trudy Nikitskogo botanicheskogo sada. 1964. T. 37. S. 472-488. 